IJLR: International Journal of Law Recontruction

Volume 5, Number 1, April 2021

DOI : http://dx.doi.org/10.26532/ijlr.v5i1.15540

\title{
POLITICAL CHANGING FOR PRIME MINISTER OF JAPAN
}

\author{
Osamu Ryoichi \\ Nagoya University, Japan \\ ryoichio@gmail.com
}

\begin{abstract}
The prime minister of Japan (日本国内閣総理大臣, Nihon-koku naikaku sōridaijin, or shushō (首相)) (informally referred to as the PMOJ) is head of the government of Japan, the chief executive of the National Cabinet and the commander-in-chief of the Armed Forces of Japan; he is appointed by the emperor of Japan after being designated by the National Diet and must enjoy the confidence of the House of Representatives to remain in office. He is the head of the Cabinet and appoints and dismisses the other ministers of state. The literal translation of the Japanese name for the office is Minister for the Comprehensive Administration of (or the Presidency over) the Cabinet. The current prime minister of Japan is Yoshihide Suga. On 14 September 2020, he was elected to the presidency of the governing Liberal Democratic Party (LDP). After being confirmed in the Diet, he received an invitation from Emperor Naruhito to form a government as the new prime minister, and took office on 16 September 2020. Japan's parliament has elected Yoshihide Suga as the country's new prime minister, following the surprise resignation of Shinzo Abe. After winning the leadership of the governing party earlier this week, Wednesday's vote confirms the former chief cabinet secretary's new position. It happened because the needed of political interest for Japan.
\end{abstract}

Keywords: Party; Politic; Power; Prime Minister;

\section{A. INTRODUCTION}

Before the adoption of the Meiji Constitution, Japan had in practice no written constitution. Originally, a Chinese-inspired legal system known as ritsuryō was enacted in the late Asuka period and early Nara period. It described a government based on an elaborate and rational meritocratic bureaucracy, serving, in theory, under the ultimate authority of the Emperor; although in practice, real power was often held elsewhere, such as in the hands of the Fujiwara clan, who intermarried with the Imperial Family in the Heian period, or by the ruling shōgun. Theoretically, the last ritsuryō code, the Yōrō Code enacted in 752, was still in force at the time of the Meiji Restoration ${ }^{1}$.

1 政府専用機にそもそも「専用機材」は必要なのか?，Newsweek Japan，Feb 25，2011. The Cabinet shall resign en masse after a general election of members of the House of Representatives. Their term of office is four years which can be terminated earlier. No limits are imposed on the number of terms or tenures the Prime Minister may hold. The Prime Minister is, 
Under this system, the Daijō-daijin (太政大臣, Chancellor of the Realm) was the head of the Daijō-kan (Department of State), the highest organ of Japan's pre-modern Imperial government during the Heian period and until briefly under the Meiji Constitution with the appointment of Sanjo Sanetomi in 1871. The office was replaced in 1885 with the appointment of Itō Hirobumi to the new position of Prime Minister, four years before the enactment of the Meiji Constitution, which mentions neither the Cabinet nor the position of Prime Minister explicitly. It took its current form with the adoption of the Constitution of Japan in 1947.

To date, 64 people have served this position. The longest serving prime minister to date is Shinzō Abe, who served as prime minister in two terms: from 26 September 2006 until 26 September 2007, and from 26 December 2012 until 16 September 2020.

\section{B. RESEARCH METHODS}

The method used in this research is descriptive normative to analyze the political problems contained in the legislation related to the problem under study with historical analytized. The problem approach used is the statute approach and conceptual approach. The legal materials that have been collected or encountered must be separated according to their respective categories and then interpreted in an effort to achieve answers to research problems. Then process and interpret legal materials in order to get conclusions from the problem, and explain the conclusions, which in this case are qualitative conclusions.

\section{RESULT AND DISCUSSION}

\section{Japan Prime Minister System}

The prime minister is designated by both houses of the Diet, before the conduct of any other business. For that purpose, each conducts a ballot under the run-off system. If the two houses choose different individuals, then a joint committee of both houses is appointed to agree on a common candidate. Ultimately, however, if the two houses do not agree within ten days, the decision of the House of Representatives is deemed to be that of the Diet. Therefore, the House of Representatives can theoretically ensure the appointment of any prime minister it wants. The candidate is then presented with his or her commission, and formally appointed to office by the Emperor ${ }^{2}$.

In practice, the prime minister is almost always the leader of the majority party in the House of Representatives, or the leader of the senior partner in the governing coalition.

by convention, the leader of the victorious party, though some prime ministers have been elected from junior coalition partners or minority parties.

2 Administrative Litigation Act, article 27 
a. Qualifications ${ }^{3}$

1) Must be a member of either house of the Diet. (This implies a minimum age of 25 and a Japanese nationality requirement.)

2) Must be a "civilian". This excludes serving members of the Japan Self-Defense Forces. Former military persons may be appointed prime minister, Yasuhiro Nakasone being one prominent example.

b. Constitutional roles ${ }^{4}$

1) Exercises "control and supervision" over the entire executive branch.

2) Presents bills to the Diet on behalf of the Cabinet.

3) Signs laws and Cabinet orders (along with other members of the Cabinet).

4) Appoints all Cabinet ministers, and can dismiss them at any time.

5) May permit legal action to be taken against Cabinet ministers.

6) Must make reports on domestic and foreign relations to the Diet.

7) Must report to the Diet upon demand to provide answers or explanations.

8) May advise the Emperor to dissolve the Diet's House of Representatives.

C. Statutory roles ${ }^{5}$

1) Presides over meetings of the Cabinet.

2) Commander-in-chief of the Japan Self-Defense Forces.

3) May override a court injunction against an administrative act upon showing of cause.

Unlike most of his counterparts in constitutional monarchies, the prime minister is both de jure and de facto chief executive. In most other constitutional monarchies, the monarch is nominal chief executive, while being bound by convention to act on the advice of the cabinet. In contrast, the Constitution of Japan explicitly vests executive power in the Cabinet, of which the prime minister is the leader. His countersignature is required for all laws and Cabinet orders. While most ministers in parliamentary democracies have some freedom of action within the bounds of cabinet collective responsibility, the Japanese Cabinet is effectively an extension of the prime minister's authority.

d. Official office and residence ${ }^{6}$

It is located near the Diet building, the Office of the Prime Minister of Japan is called the Kantei (官邸). The original Kantei served from 1929 until 2002, when a new building was inaugurated to serve as the current Kantei. The old Kantei was then converted into the Official

3 Article 5 of the Constitution of Japan

4 Article 55 of the Imperial Constitution only bound the ministers of state, i.e. all members of the cabinet including the prime minister, to "give their advice to the Emperor and be responsible for it."

5 Article 6 of the Constitution of Japan

6 Cabinet Act 2012, article 4 and Jump up to: a b Article 72 of the Constitution of Japan 
Residence, or Kōtei (公邸). The Kōtei lies to the southwest of the Kantei, and is linked by a walkway.

e. Travel $^{7}$

The prime minister of Japan travels in a Lexus LS 600h L, the official transport for the head of government, or an unmodified Toyota Century escorted by a police motorcade of numerous Toyota Celsiors. For long-distance air travel, Japan maintains two Boeing 747-400 aircraft mostly for the prime minister of Japan, the emperor, empress and other members of the imperial family, operated by the Japan Air Self-Defense Force.

They have the radio callsigns Japanese Air Force One and Japanese Air Force Two when operating on official business, and Cygnus One and Cygnus Two when operating outside of official business (e.g., on training flights). The aircraft always fly together on government missions, with one serving as the primary transport and the other serving as a backup with maintenance personnel on board. The aircraft are officially referred to as Japanese government exclusive aircraft (日本国政府専用機, Nippon-koku seifu sen'yōki).

The aircraft were constructed at the Boeing factory at the same time as the U.S. Air Force One VC-25s, though the U.S. aircraft were built to the 747-200 design, while the Japanese aircraft were built to the more contemporary 747-400 design. Both Japanese aircraft were delivered in 1990 . The $747 \mathrm{~s}$ will be replaced by new Boeing 777-300ER aircraft in fiscal year 2019.

Until the mid-1930s, the prime minister of Japan was normally granted a hereditary peerage (kazoku) prior to leaving office if he had not already been ennobled. Titles were usually bestowed in the ranks of count, viscount or baron, depending on the relative accomplishments and status of the prime minister. The two highest ranks, marquess and prince, were only bestowed upon highly distinguished statesmen, and were not granted to a prime minister after 1928. The last prime minister who was a peer was Baron Kijūrō Shidehara, who served as Prime Minister from October 1945 to May 1946. The peerage was abolished when the Constitution of Japan came into effect in May 1947.

Certain eminent prime ministers have been awarded the Order of the Chrysanthemum, typically in the degree of Grand Cordon. The highest honour in the Japanese honours system, the Collar of the Order of the Chrysanthemum, has only been conferred upon select prime ministers and eminent statesmen; the last such award to a living prime minister was to Saionji Kinmochi in 1928. More often, the Order of the Chrysanthemum has been a posthumous distinction; the Collar of the

7 Jump up to: $a$ b "A virtual tour of the former Kantei - Annex etc. - The Residential Area". Prime Minister of Japan. Retrieved 21 October 2020. 
order was last awarded posthumously to former prime minister Yasuhiro Nakasone in November 2019. The Grand Cordon has typically been posthumously awarded; the most recent such award was to Ryutaro Hashimoto in July $2006^{8}$.

After relinquishing office, the prime minister is normally accorded the second or senior third rank in the court order of precedence, and is usually raised to the senior second rank posthumously. Certain distinguished prime ministers have been posthumously raised to the first rank; the last such award was to Sato Eisaku in 1975. Since the 1920s, following their tenure in office, Prime ministers have typically been conferred with the Grand Cordon of the Order of the Paulownia Flowers (until 2003 a special higher class of the Order of the Rising Sun), depending on tenure and eminence. However, honours may be withheld due to misconduct or refusal on the part of the prime minister (for example, Kiichi Miyazawa).

Japanese Prime Minister Naoto Kan survived a no-confidence vote in Parliament on Thursday, but his victory came at a high, seemingly self-defeating cost: Kan promised to resign as soon as the earthquakesparked nuclear crisis is over. When Kan steps down, he will be the fourth Japanese Prime Minister to do so since 2007, when Shinzo Abe resigned less than a year into his term. Abe, in his resignation address, cited the same rationale as would Prime Minister Yasuo Fukuda in 2008, Prime Minister Yukio Hatoyama in 2010, and Prime Minister Kan did this week: unpopularity. (Taro Aso, elected in 2008, was defeated in a 2009 election, never getting the chance to resign.) Their poll numbers had dropped, the Parliament had split, and, according to the resignation announcements, their unpopularity had made neither the prime minister nor the government itself able to effectively government ${ }^{9}$.

\section{So why is Japan different?}

Why do its top officials and this trend extends across senior government posts resign office, seemingly at the drop of a hat? The theories are endless, most of them relying on oft-repeated but simplistic stereotypes about the supposed centrality of honor, saving face, and respect in Japanese culture. But if these traits really are so important to Japanese culture, then the same could be said of Arab culture. But, clearly, Arab political leaders feel no compunction to step down, even if they become so loathed that the country rises up by the millions to demand their exit. There is no consensus on why Japan's prime ministers are so frail. Some put it down to the fact that the ultimate stability resides in the emperor, and dismissing a prime minister is no more traumatic than changing the coach of

8 Ibid.

9https://www.theatlantic.com/international/archive/2011/06/why-do-japanese-prime-ministers-

keep-resigning/239850/ Retrieved 28 April 2021 
a baseball team. Others point to the postwar education system. Prime ministers have relatively low salaries, little authority even within cabinet, and limited terms. Whatever it is, Japan could do with one who can stay around for more than a year. All applications are welcome.

Whatever the personal motivation driving these men's (and Japan's senior politicians are almost always men) decisions, the effect has been to establish a radically direct sort of democracy. Kan clearly felt that he was expected to resign, as did his predecessors before him. Every such resignation, of which there have been many in the past five years, reinforces a new norm: if a politician becomes too unpopular, he must resign. The more repeated and expected this behavior becomes, the more that voters and politicians alike will assume that this is simply how Japan's system works.

Unlike in the American system, where politicians are elected to terms that they expect to hold unless they are impeached through a complicated and transparent legal process, this new Japanese system offers no such expectation, hanging officials by the narrow thread of popular opinion. Anything that frays that thread -- an unpopular military deal, an environmental disaster, a particularly ugly shirt -- could push a Prime Minister or other official to resign. And this is about more than just habit. Japan's minority parties now know that the public will expect any disgraced official to resign. So minority parties in Parliament will feel free to do what they have done in the past, should a Prime Minister become unpopular: totally deadlock the government until he resigns ${ }^{10}$.

Japan's political culture of existential popular accountability, in which any politician could feel compelled to resign at any time if popular opinion turns, might be more democratic -- in a sense, Japanese choose whether or not to reelect every time they answer an opinion poll -- but is it more effective? The U.S. system, after all, was designed to internalize majority public opinion, but also to protect against it: Supreme Court justices serve lifelong terms, legislation is passed by representatives rather than by referendum (except in California, which instituted the referendum system to catastrophic results), and elected officials take their full terms in all but the most extreme cases. At some point, government officials must be allowed to do what they think is right, not merely what is popular, if that government is to function. But whoever succeeds Kan, knowing that a dip in approval would mean widespread expectations of resignation, will feel pressured to maintain day-to-day popularity at all costs. Japan's problems are too vast, and its strengths too great, to be ruled by something as capricious and frivolous as the whims of the majority.

10 Japanese Prime Minister Shinzo Abe officially resigns. CBSNews. AP. 16 September 2020. See Kenkyusha's New Japanese-English Dictionary, Kenkyusha Limited, ISBN 4-7674-2015-6 


\section{Why Do Japan Change Prime Ministers So Often?}

In the 1990s Japan introduced single-seat constituencies to their electoral systems in an attempt to encourage two-party politics. Since then both have had frequent changes of prime minister. Political scientist Ikeya Tomoaki examines the similarities and differences in the workings of the two countries' political systems.

It has often been noted that Japanese politics share similarities going back a number of decades. In 1955 Japan's two conservative parties merged to form the Liberal Democratic Party, and the left-wing and right-wing Socialists were reunited in the Japan Socialist Party. There were hopes that this would lead to a two-party political system where power would alternate between the parties at a reasonable frequency. The reality, however, was that in the years that followed the conservatives ended up having about twice as many parliamentary seats as the socialists, producing what came to be called a "one-and-a-half-party system," where the LDP never lost power to the JSP.

Heightened demands for political reform brought changes to the electoral systems at around the same time 1994 in Japan. Although the details differed somewhat, Japan adopted systems consisting mainly of "first past the post" single-seat constituencies, with smaller sets of seats assigned by proportional representation. The introduction of single-seat constituencies was expected to promote two-party politics and thereby achieve the objective of having power periodically change hands between the parties.

Japanese prime ministers have changed often in recent years, and this has also been cited as a similarity between the two countries' political systems. In Japan, from the Hosokawa Morihiro cabinet that took office in August 1993 to the current Abe Shinzō cabinet formed in December 2012, there have been 18 cabinets and 13 prime ministers. If we restrict our view to the period since Japan's current electoral system was implemented (in the House of Representatives election of 1996), then we start with the Hashimoto Ryūtarō cabinet of November 1996, giving a total of 14 cabinets and 10 prime ministers; there were 10 cabinets and 6 prime ministers ${ }^{11}$.

The turnover rate of government leaders in Japan is much higher than in other parliamentary democracies like Germany or Britain. From 1993 to the present, Germany has had a mere three chancellors (Helmut Kohl, Gerhard Schröder, and Angela Merkel), while Britain has had just four prime ministers (John Major, Tony Blair, Gordon Brown, and David Cameron).

One important difference that many have cited is the role of the upper house in these countries' bicameral legislatures. Germany's Bundesrat represents the country's 16 Länder (federal states) at the national level, and

11 Nakata, Hiroko (6 March 2007). "The prime minister's official hub". The Japan Times Online. The Japan Times. Retrieved 21 October 2020. 
the powers of Britain's House of Lords are severely limited. In neither country does the upper house have the power to push the government leader out of office.

In Japan, if a bill passed by the House of Representatives (the lower house) is subsequently rejected, revised, or not acted on within 60 days by the House of Councillors, it can still become law if the lower house passes it again by a two-thirds majority. Although the superiority of the lower house is thus defined in the Constitution, the two-thirds majority requirement is a high hurdle to clear, meaning that the upper house actually wields substantial power.

\section{The Revolving Door of the Japanese Prime Minister's Office}

In Japan, a coalition of opposition parties ousted the long-ruling Liberal Democratic Party after the 1993 general election. However, the Liberal Democrats returned to power the following year by forming a coalition with the Socialists, their traditional opponents. At that point they agreed to have Socialist leader Murayama Tomiichi become prime minister, but in 1996 they also retook the premiership, which was assumed by LDP President Hashimoto Ryūtarō. The LDP maintained power in a series of coalition governments under the new electoral system until the 2009 general election, when the Democratic Party of Japan drove it from power.

Does the power held by the House of Councillors cause the frequent change of prime ministers? Elections for the House of Councillors are held regularly every three years, generally occurring in the intervals between general elections for the lower house (whose members are elected for fouryear terms), and it is certainly true that the results of these elections can have an impact on the administration. For example, following the defeat of the LDP in the 1998 upper house election, Prime Minister Hashimoto was forced to step down midway through his electoral term. Even if the prime minister does not resign, a defeat in an upper house election can weaken the administration's political foundation ${ }^{12}$.

Particularly in the case of "divided government," where the ruling party or coalition lacks a majority in the upper house, the split causes instability in government administration and weakens the prime minister's authority. In recent years Abe Shinzō (who served his first term as prime minister from 2006 to 2007), Fukuda Yasuo (Abe's successor, 2007-8), and the DPJ's Kan Naoto (2010-11) have all been pushed out of office while there was a divided government. Divided governments and the powerful upper house alone, however, do not fully explain why prime ministers change more frequently in Japan. Prime ministers Mori Yoshirō (2000-2001), Koizumi Jun'ichirō (2001-6), and the DPJ's Hatoyama Yukio (2009-10) all left office

12 Sanchanta, Mariko; Inada, Miho (4 February 2010). "Toyota's Influence Looms Over Japan". The Wall Street Journal. Archived from the original on 29 May 2015. Retrieved 13 May 2020. 
when the government was not divided.

\section{The Negative Impact of the LDP's Term Limits}

The missing element from this analysis is the effect of the LDP's internal regulations in shortening prime ministers' terms in office. The term of the LDP presidency is set at three years (and was only two years until 2003). At the end of this term the president must seek reelection or step down even if he is only partly through his electoral term as prime minister, as is generally the case. Some have argued that the posts of party president and prime minister should be separated, but so far this has not come to pass. As the situation presently stands, if a prime minister fails to win reelection as LDP president, he loses the premiership as well13.

So the party that produces most of Japan's prime ministers has its own mechanism for replacing them regularly. An example is Fukuda Takeo, who lost the LDP's presidential election in 1978 and had to resign as prime minister. Although there have been no similar cases in recent years, it is very strange for a ruling party to pull the rug out from under its own leader like this, and it shows disregard for the will of other parties in the ruling coalition and for the general public.

To make matters worse, party rules state that if an LDP president resigns in the middle of his term, the new president's term is just the remainder of his predecessor's. There is also a rule stating that presidents cannot serve more than two terms in succession. So the limits placed on LDP leaders by their own party are extremely severe. Koizumi, who was still very popular with the public when he stepped down as prime minister at the end of his second term as LDP president in 2006, did not even have the option of seeking another term at that point (leaving aside the question of whether he wanted to stay on).

In Britain, by comparison, though Prime Minister Margaret Thatcher was forced to leave office when the Conservatives voted her out as their party leader in 1990, this was after she had been leading the country for more than 10 years. The Conservative and Labour parties hold leadership elections, of course, but there are no set terms for leaders. In Germany, party leaders do have fixed terms, and sometimes they are voted out, but the party leader's post is not necessarily linked to the post of chancellor. For example, Gerhard Schröder served as chancellor (1998-2005) without being the head of the Social Democratic Party ${ }^{14}$.

In Japan, there are often cases of feuding within ruling parties, which lead to demands from ruling-party Diet members for the prime minister to step down (this is not limited to the LDP but was also seen in the DPJ when it was in power). These ruling-party members are supposed to support their

13 Ibid.

14 Yoshihide Suga set to become Japan's prime minister after winning LDP election. The Japan Times. 14 September 2020. Retrieved 14 September 2020. 
leader. Instead, they instigate movements to topple the government, so it is no wonder that cabinets lack stability. The lifetime of any prime minister is a function of his party members' support.

\section{Party Unity and Prime Ministerial Competence}

In order for Japan's prime ministers to stay in office longer, it may be important to reform the institution of the upper house, but what is probably even more important is to achieve unity within the party whose leader is the prime minister and between that party and its coalition partners. And of course, it is also vital that the prime minister be highly competent in managing his party and the ruling coalition in order to push forward with the political agenda.

\begin{tabular}{|c|c|c|c|c|c|}
\hline \multicolumn{6}{|c|}{ Japanese Prime Ministers since 1998-Now ${ }^{15}$} \\
\hline \multirow{4}{*}{$\begin{array}{c}\text { No. } \\
1\end{array}$} & \multirow{4}{*}{$\begin{array}{c}\text { Name } \\
\text { Keizō } \\
\text { Obuchi } \\
\text { 小湔 恵三 } \\
\text { Rep } \\
\text { for Gunma } \\
\text { 5th } \\
(1937-2000)\end{array}$} & \multicolumn{3}{|c|}{ Duration } & Party \\
\hline & & 30 July 1998 & 5 April 2000 & - & $\begin{array}{c}\text { Liberal } \\
\text { Democratic }\end{array}$ \\
\hline & & & & & \\
\hline & & 2 years & and 201 days & & \\
\hline \multirow[t]{4}{*}{2} & \multirow{4}{*}{$\begin{array}{l}\text { Yoshirō Mori } \\
\text { 森 喜朗 } \\
\text { Rep } \\
\text { for Ishikawa } \\
\text { 2nd } \\
\text { (born 1937) }\end{array}$} & 5 April 2000 & 26 April 2001 & - & Liberal \\
\hline & & & & 2000 & Democratic \\
\hline & & 1 yea & and 22 days & & \\
\hline & & & & & \\
\hline \multirow[t]{6}{*}{3} & \multirow{6}{*}{$\begin{array}{c}\text { Junichirō } \\
\text { Koizumi } \\
\text { 小泉 純一郎 } \\
\text { Rep } \\
\text { for Kanagawa } \\
\text { 11th } \\
\text { (born 1942) }\end{array}$} & 26 April 2001 & 26 September 2006 & - & Liberal \\
\hline & & & & $\begin{array}{l}2003 \\
2005\end{array}$ & Democratic \\
\hline & & 5 years & and 154 days & & \\
\hline & & & & & \\
\hline & & & & & \\
\hline & & & & & \\
\hline \multirow[t]{5}{*}{4} & \multirow{5}{*}{$\begin{array}{l}\text { Shinzō Abe } \\
\text { 安倍 晋三 } \\
\text { Rep } \\
\text { for Yamaguchi } \\
\text { 4th } \\
\text { (born 1954) }\end{array}$} & 26 September 2006 & 26 September 2007 & - & Liberal \\
\hline & & 1 ye & ar and 1 day & & Democratic \\
\hline & & & & & \\
\hline & & & & & \\
\hline & & & & & \\
\hline 5 & Yasuo & 26 September 2007 & 24 September 2008 & - & Liberal \\
\hline
\end{tabular}

15 Kantei: Cabinet System of Japan 1998-2021 


\begin{tabular}{|c|c|c|c|c|}
\hline & $\begin{array}{c}\text { Fukuda } \\
\text { 福田 康夫 } \\
\text { Rep } \\
\text { for Gunma } \\
\text { 4th } \\
\text { (born 1936) }\end{array}$ & 365 days & & Democratic \\
\hline \multirow[t]{2}{*}{6} & Tarō Asō & 24 September $2008 \quad 16$ September 2009 & - & \multirow{2}{*}{$\begin{array}{c}\text { Liberal } \\
\text { Democratic }\end{array}$} \\
\hline & $\begin{array}{c}\text { 麻生 太郎 } \\
\text { Rep } \\
\text { for Fukuoka } \\
\text { 8th } \\
\text { (born 1940) }\end{array}$ & 358 days & & \\
\hline \multirow[t]{2}{*}{7} & Yukio & 16 September $2009 \quad 8$ June 2010 & 2009 & \multirow[t]{2}{*}{ Democratic } \\
\hline & $\begin{array}{c}\text { Hatoyama } \\
\text { 鳩山 由紀夫 } \\
\text { Rep } \\
\text { for Hokkaido } \\
\text { 9th } \\
\text { (born 1947) }\end{array}$ & 266 days & & \\
\hline \multirow[t]{2}{*}{8} & Naoto Kan & 8 June $2010 \quad 2$ September 2011 & - & \multirow[t]{2}{*}{ Democratic } \\
\hline & $\begin{array}{c}\text { 菅 直人 } \\
\text { Rep for Tokyo } \\
18 \text { th } \\
\text { (born 1946) }\end{array}$ & 1 year and 87 days & & \\
\hline \multirow[t]{2}{*}{9} & Yoshihiko & 2 September 201126 December 2012 & - & \multirow[t]{2}{*}{ Democratic } \\
\hline & $\begin{array}{c}\text { Noda } \\
\text { 野田 佳彦 } \\
\text { Rep for Chiba } \\
\text { 4th } \\
\text { (born 1957) }\end{array}$ & 1 year and 116 days & & \\
\hline \multirow[t]{2}{*}{10} & $\begin{array}{c}\text { Shinzō Abe } \\
\text { 安倍 晋三 } \\
\text { Rep }\end{array}$ & 26 December 201216 September 2020 & $\begin{array}{l}2012 \\
2014 \\
2017\end{array}$ & \multirow[t]{2}{*}{$\begin{array}{c}\text { Liberal } \\
\text { Democratic }\end{array}$} \\
\hline & $\begin{array}{c}\text { for Yamaguchi } \\
\text { 4th } \\
\text { (born 1954) }\end{array}$ & 7 years and 266 days & & \\
\hline 11 & $\begin{array}{c}\text { Yoshihide } \\
\text { Suga } \\
\text { 菅 義偉 } \\
\text { Rep } \\
\text { for Kanagawa } \\
\text { 2nd } \\
\text { (born 1948) }\end{array}$ & 16 September 2020 & - & $\begin{array}{c}\text { Liberal } \\
\text { Democratic }\end{array}$ \\
\hline
\end{tabular}




\section{Domestic problems may take precedence over foreign policy}

At the outset, the new prime minister may be occupied by trouble at home. The 71-year-old inherits an economy battered by COVID-19, which he will have to attempt to resuscitate despite a shrinking and aging population. He will also have to determine the fate of the postponed Tokyo Olympics.

Abe faced public scrutiny for his handling of the virus. Although Japan's response has been more effective than many other nations, many in Japan perceived the national government's response as too slow. As of Sept. 17 , about 1,480 people have died and 77,000 have been infected in Japan. Even while juggling a busy domestic agenda, Suga will still have to do a balancing act between the U.S. and China, one made no easier by particularly fraught relations between the superpowers.

Jeff Kingston, Director of Asian Studies at Temple University's Tokyo campus, tells TIME that Suga will prioritize U.S. relations, but he will also seek to maintain the thaw in relations with China. Economic ties between Japan and China had improved under Abe, but historic tensions remain and Chinese incursions into Japanese waters around the disputed Senkaku Islands (known as the Diaoyu Islands in China) have caused agitation. China expects to deepen cooperation on fighting COVID-19 and to grow economic ties, according to foreign ministry spokesperson Wang Wenbin.

Suga has also said that he wants to resolve some unfinished business on the diplomatic front. Abe had failed in his goal to resolve several wartime legacies, including normalizing ties with North Korea and signing a peace treaty with Russia to formally end their hostilities in World War II.

In early September, Suga told a news conference that he would consider meeting North Korean Leader Kim Jong-Un without preconditions. He said that he wants to "make a breakthrough" on the issue of the abduction of Japanese nationals by Pyongyang in the 1970s and 1980s, a goal that Abe said he regretted not achieving. As far as North Korea diplomacy on nuclear issues goes, it will be important for Japan to continue working closely with the U.S., says Nakabayashi of Waseda University. Even as some in Japan worry about the rare uncertainty this new administration brings, experts say the U.S.-Japan alliance is likely to remain stable under Suga. "If he follows Abe, and that seems likely, he will seek a better economic relationship with China despite differences on security, territory and history and do whatever it takes to keep Uncle Sam engaged to provide security," says Kingston of Temple University. About 54,000 U.S. troops are deployed in Japan, and the country hosts the U.S. Navy's Seventh Fleet. Japan's post-World War II "pacifist" constitution renounced war, and Abe 
left office without fulfilling long cherished plans to alter the charter ${ }^{16}$.

Plus, says Kristi Govella, an assistant professor of Asian Studies at the University of Hawaii at Mānoa, the foundations of the U.S.-Japan alliance run much deeper than ties between individual leaders. "The U.S. and Japan share significant interests and values that give them strong incentives to maintain good relations with each other, and this is unlikely to change under a Suga administration," she says. "Japan is a key U.S. partner in dealing with China and North Korea and maintaining stability in the region more broadly."

\section{Japan welcomed a new prime minister on Sep. 16, 2020.}

Japan's parliament has elected Yoshihide Suga as the country's new prime minister, following the surprise resignation of Shinzo Abe. After winning the leadership of the governing party earlier this week, Wednesday's vote confirms the former chief cabinet secretary's new position. A close ally of $\mathrm{Mr}$ Abe, the new prime minister is expected to continue his predecessor's policies. Shinzo Abe announced his resignation last month citing ill health. Earlier on Wednesday, Mr Abe held his final cabinet meeting and told reporters he was proud of his achievements during his nearly eight years in power. Mr Suga then easily won a poll for prime minister in the Diet, Japan's lower house, receiving 314 out of 462 votes. Given that a coalition headed by his conservative Liberal Democratic Party (LDP) holds the majority in the house, his win was widely expected. Along with his new cabinet he will later be ceremonially endorsed by the emperor at the Imperial Palace.

A veteran politician and long-time cabinet member he takes the lead at a difficult time for the world's third-largest economy. Like many other nations, Japan is struggling with the coronavirus pandemic which has caused the biggest economic slump on record following years of economic stagnations. The country is also dealing with a rapidly ageing society, with nearly a third of the population older than 65 .

Yoshihide Suga was born the son of strawberry farmers, the veteran politician comes from a humble background that sets him apart from much of Japan's political elite. The 71-year rose only slowly within the political ranks. He first worked as a secretary for an LDP lawmaker before eventually embarking on his own political career, from city council elections to becoming a member of the Diet in 1996.

In 2005 he became a cabinet minister under Junichiro Koizumi and gained further influence in the subsequent Abe cabinet. As Mr Abe's righthand man, he gained a reputation for being efficient and practical and the

16 Legal framework for Prime Minister and Cabinet in the Empire: Dajōkan proclamation No. 69 of 22 December 1885 (内閣職権, naikaku shokken), later replaced by Imperial edict No. 135 of 1889 (内閣官制, naikaku kansei) Archived March 3, 2020, at the Wayback Machine in effect until 1947 
outgoing prime minister strongly supported his ally's bid for the leadership. One of his most prominent public appearances was when he unveiled the name of the new Reiwa era during the transition from Emperor Akihito, who abdicated, to his son Naruhito in 2019. Yet as he takes over mid-term, many observers expect him to only serve out the remainder of that until a general election late next year. When he won his landslide within the LPD on Monday, all he needed was support from his own party. Next year's election, however, will put him in front of a general electorate - and the low-key veteran politician might not be the LDP's first choice for that, observers say.

Yoshihide Suga, who was formerly Abe's closest aide and the Chief Cabinet Secretary of Japan, was elected by the Diet as Abe's successor. In his campaign, he promised continuity, saying that he will build on "Abenomics", one of the legacies left behind by his predecessor. As the longest-serving prime minister of Japan, having stayed the course for eight years, Abe managed to buck a trend of short-lived premierships. While Abe became prime minister for the first time in 2006, he stepped down shortly in 2007 due to ulcerative collitis. He ran again in 2012, and stayed in power for nearly eight years before stepping down last month. With the exception of Abe and Junichiro Koizumi, no prime minister in Japan has managed to stay in office longer than two years in the last 20 years since 2000. Before Abe, various factors could trigger a prime minister's resignation possibly even what they wear, after former prime minister Yukio Hatoyama was attacked for making a fashion faux pas, according to The Atlantic. Donning a multicoloured shirt, a fashion critic lambasted his fashion choice in a public magazine, warning the country that the clownish attire represented what poll numbers already reflected -- that Hatoyama was out of touch.

While Abe's resignation is mainly tied to his health issues, his popularity had dipped considerably. His approval ratings fell alarmingly low in May 2020, according to polls by NHK and Mainichi, reported Japan Times. While Abe's popularity remained low right before his resignation, public support poured in after his resignation, for his record-setting run as the longest-serving prime minister of Japan and Suga's promise of continuity as his successor. The approval rating for Suga's Cabinet stands at 66.4 per cent according to a poll by Kyodo, one of the highest among prime ministers taking office since 2000.

The culture of resignation possibly due to the lack of popularity may have been reinforced by each resignation by the politicians' predecessors, creating an assumption that this may be how Japan's political system works. While Japan's Liberal Democratic Party (LDP) has largely dominated the political scene with few exceptions in the last two decades. Within the LDP exists various internal factions, which have been around since the beginning days of the LDP in 1955.

According to research by Columbia University, many politicians in the LDP belong to an internal faction, as faction leaders are able to provide 
resources and connections for their followers, which would help them in taking care of their constituents. There are seven factions in the LDP, with the largest faction led by Hiroyuki Hosoda, a former Chief Cabinet Secretary. Abe also belonged to this faction, which was once led by his late father, Shintaro Abe, who was foreign minister from 1982 to 1986 . While the longserving Abe has seen his popularity fluctuate across the years, he remained largely unchallenged within the LDP due to his heavy influence in the party. Coming from political "royalty", Abe's grandfather Nobusuke Kishi was the former prime minister of Japan, and his father was also a political heavyweight.

Abe's political backing and influence managed to overcome internal differences, possibly resulting in a much longer-lasting premiership than most. Junichiro Koizumi, another former prime minister who served from 2001 to 2006, was also a third-generation politician. He is also part of the same faction as Abe. His son, Shinjiro Koizumi, the current environment minister of Japan, has been earmarked as a future prime minister by political observers across Japan, according to Financial Times. Of Japan's 30 prime ministers since WWII, only three have had no political family background. Some 45 per cent of MPs in Japan inherited their seats from their fathers up until the 1990s, Australian National University research found, reported Sydney Morning Herald.

The current Prime Minister Suga can be considered a political anomaly in Japan, as he does not belong to any faction. In 1996, Suga was elected to the lower house of parliament at the relatively mature age of 47 . However, despite being factionless, five out of seven LDP factions have been fighting to support him as the new prime minister, with them backing him in the recent internal election. Suga maintained that he would not reward supportive factions with Cabinet posts, in an interview with Asahi Shimbun during the internal election in early September. It remains a question whether Suga will be able to retain his power in the long run, or if Japan's premierships will revert to pre-Abe days, with short-lived seasons. Much of it may depend on Suga's performance in the upcoming national election that must be called by September 2021.

It was about 14 years ago that the fresh faced Abe claimed the Prime Ministerial position in Japan. He did this in spite of many in the Liberal Democratic Party (LDP) considering him far too young to run the country. Abe then resigned from the position the following year due to health concerns. He however began his second Prime Ministerial tenure in 2012, after being convinced to run. He also worked in a myriad of jobs, including as a security guard, and manual work in Tsukiji fish market while saving enough money for his university education. He then attended university at Hosei, because it was the cheapest private university at the time. Considering the background his predecessors come from, the appointment of Suga as the next Prime Minister feels almost revolutionary in a sense. 
According to Sydney Morning Herald, only three of Japan's 30 post-war prime ministers have had no political family background: "Of Japan's 30 post-war prime ministers, only three have had no political family background. Up until the 1990s, 45 per cent of MPs inherited their seats from their fathers, Australian National University research found." His political career wasn't that of your typical prime minister either. In 1996, Suga was elected to the lower house of parliament at the relatively mature age of 47. In fact, an AP article touched on Suga's personality through an anecdote of his younger days playing baseball: "Suga, who played baseball in junior high school, insisted on keeping his batting stance despite an instructor's advice, saying his style made better sense, his old friend Yuri Masashi told the Mainichi newspaper.

Apparently Suga was not talking off the cuff, and practiced and mastered the technique of a pro baseball star from Akita. "Once he makes a decision, he never sways and he is still the same," Masashi said." He is perhaps best known to the world at large for his role in ushering in Japan's new Reiwa era, a role that earned him the nickname "Uncle Reiwa". While he was also tasked with meeting Mike Pompeo, Suga is more known for local policy making.

US Secretary of State Mike Pompeo (L) speaks to Japan's Chief Cabinet Secretary Yoshihide Suga at the Prime Ministers office in Tokyo on October 6, 2018. - Pompeo said he hoped to accelerate a second summit between Kim Jong Un and Donald Trump as he kicked off an Asian trip on October 6 featuring a meeting with North Korea's leader. Photo by Eugene Hoshiko/AFP via Getty Image. According to Japan Times, Suga appears to be more focused on "populist-style policies" such as boosting inbound tourism, and slashing handphone bills.

The nation's longest-serving Chief Cabinet Secretary is also known for his no-nonsense approach to handling governmental personnel. Here is one such example from Japan Times: "This tactic was exemplified by the initiative Suga took in establishing the Cabinet Bureau of Personnel Affairs in 2014, which paved the way for the prime minister to appoint, at his own discretion, a significant number of elite bureaucrats at ministries and agencies of the central government." That nose to the grindstone approach served him well during the 2009 Lower House elections where the LDP was unceremoniously booted from power by a wave of support for The Democratic Party of Japan. The DPJ won 308 seats out of 480 seats.

One of the few LDP politicians who survived? Suga. The Nikkei Asian Review credited that victory in part to Suga's man-on-the-ground, literally, campaign style. "During his election campaigns, he could be seen every morning standing in front of a train station, greeting businesspeople who were commuting from Yokohama to Tokyo, speaking about his policy proposals and conducting surveys. This grass roots campaigning helped him survive the 2009 lower house election, which gave the LDP a bloody nose. 
Over the years since then, Suga has built an unshakable support base. ${ }^{17 "}$ Another defining point of his political career has been his loyalty to Shinzo Abe. When Abe was deemed too young by his LDP colleagues, it was Suga, who formed a group of lawmakers to support his party leadership. When Abe was contemplating returning to politics after resigning as Prime Minister a year into the job, it was Suga who convinced Abe, through the use of numbers and data, that Abe could triumph in the LDP leadership election.

\section{CONCLUSION}

That loyalty is poised to continue even as Suga begins his own tenure as Prime Minister. He is set to continue Abenomics and follow Abe's current foreign policy leanings. Suga however is not a carbon copy of Abe's policies. AP noted that Suga supported allowing more foreign labourers into Japan so as to offset the inevitable workforce decline as Japan ages, a change Abe was not keen on. Ultimately the change in leadership does not appear to signal a drastic change in how Japan is run, rather an almost dogged doubling down on current policies, and a strong push to restart Japan's economy after an almost year-long battering. A commentary on CNA by Lim Tai Wei, Adjunct Senior Research Fellow at the East Asian Institute at the National University of Singapore, noted this emphasis on continuity, arguing that Japan is in good hands with Suga at the helm. "Japan is in good hands to steer through a difficult period of an ongoing pandemic and ongoing economic challenges amid rapidly-worsening US-China trade tensions." And if Japan is indeed looking to stay the path, what better candidate than someone who once a decision is made, "never sways".

\section{BIBLIOGRAPHY}

\section{Books:}

Kantei: Cabinet System of Japan 1998-2021;

Legal framework for Prime Minister and Cabinet in the Empire: Dajōkan proclamation No. 69 of 22 December 1885 (内閣職権, naikaku shokken), later replaced by Imperial edict No. 135 of 1889 (内閣官制， naikaku kansei) Archived March 3, 2020, at the Wayback Machine in effect until 1947;

\section{Journals:}

政府専用機にそもそも「専用機材」は必要なのか?，Newsweek Japan，Feb 25， 2011;

17 Op.cit. 
Japanese Prime Minister Shinzo Abe officially resigns. CBSNews. AP. 16 September 2020;

Kenkyusha's New Japanese-English Dictionary, Kenkyusha Limited, ISBN 4-76742015-6;

Nakata, Hiroko (6 March 2007), The prime minister's official hub, The Japan Times Online, The Japan Times, Retrieved 21 October 2020;

Sanchanta, Mariko; Inada, Miho (4 February 2010), Toyota's Influence Looms Over Japan, The Wall Street Journal, Archived from the original on 29 May 2015, Retrieved 13 May 2020;

Yoshihide Suga set to become Japan's prime minister after winning LDP election, The Japan Times, 14 September 2020, Retrieved 14 September 2020;

\section{Regulations:}

Administrative Litigation Act, article 27;

Article 5 of the Constitution of Japan;

Article 55 of the Imperial Constitution only bound the ministers of state, i.e. all members of the cabinet including the prime minister, to "give their advice to the Emperor and be responsible for it.";

Article 6, 7 of the Constitution of Japan;

Article 63, 67, 68 of the Constitution of Japan;

Article 74, 75 of the Constitution of Japan;

Cabinet Act 2012, article 4;;

Jump up to: a b Article 72 of the Constitution of Japan

Jump up to: $a$ b "A virtual tour of the former Kantei - Annex etc. - The Residential Area". Prime Minister of Japan. Retrieved 21 October 2020.;

Self-Defense Forces Act of 1954; 